\title{
Neurobehavioural and cognitive effects of prenatal exposure to organochlorine compounds in three year old children
}

Griet Vermeir ${ }^{1}$, Adrian Covaci ${ }^{2}$, Nik Van Larebeke ${ }^{3,4^{*}}$ D, Greet Schoeters ${ }^{5}$, Vera Nelen ${ }^{6}$, Gudrun Koppen ${ }^{5}$ and Mineke Viaene ${ }^{7,8}$

\begin{abstract}
Background: We report data of a Belgian observational prospective cohort study regarding cognitive and behavioural development until the age of 36 months in relation to internal exposure to organochlorine pollutants [sum of polychlorinated biphenyls (sum PCB), dioxin-like activity, PCB118, PCB170, hexachlorobenzene (HCB) and p, $\mathrm{p}^{\prime}$-dichlorodiphenyldichloroethylene (DDE)] measured in cord blood.

Methods: Participants were recruited as part of an Flemish Environmental Health Survey (2002-2006). Two hundred and six mother-child pairs were recruited. Hundred twenty five toddlers [Reynell Taal Ontwikkelings Schalen (language development, RTOS), Snijders-Oomen Niet-verbale intelligentietest (non-verbal intelligence, SON), Bayley Scales, milestones, Infant Behaviour Questionnaire (IBQ), gender specific play behaviour, Neurobehavioral Evaluation System (NES)-attentional task] and their mothers [Home Observation Measurement of the Environment (HOME), Wechsler Abbreviated Scale of Intelligence (WASI), State-Trait Anxiety Inventory (STAI), general questionnaires] were tested. Statistical analysis was performed with the SPSS program. Much attention was paid to confounding factors.

Results: In the first years of development, higher organochlorine pollutants were associated with less active children (delayed crawling: sum PCB*HCB $(p<0.05)$, sumPCB*DDE $(p<0.1)$; delayed first steps alone: sum PCB $(p<0.5)$, PCB1 $18(p<$ $0.01)$, PCB170 ( $p<0.01), H C B(p<0.01)$; less switching between toys: sum PCB $(p<0.01)$; less switching between toys in boys: PCB1 $18(p<0.01)$, sum PCB $(p<0.01)$ ). At 12 months children with higher dioxin-like activity tended to show less fear responses( $p<0.1)$ (IBQ 12 months). At 36 months, a slower development of language comprehension (RTOS) was related to all organochlorine exposure parameters $(p<0.1$ or $p<0.05)$ except DDE. Lower nonverbal IQ scores $(\mathrm{SON})$ were related to PCB118 in boys only $(p<0.05$ or $p<0.01)$. Less masculine and more non-gender specific play behaviour was associated with sum PCB in boys and girls at 36 months $(p<0.1)$. Moreover, PCB118 $(p<0.05), \operatorname{PCB} 170(p<0.1), \operatorname{HCB}(p<0.05)$ and $\operatorname{DDE}(p<$ 0.05 ) were associated with diminished masculine play behaviour in boys.
\end{abstract}

(Continued on next page)

\footnotetext{
* Correspondence: Nicolas.vanlarebeke@ugent.be; nikvanlarebeke@gmail.com

${ }^{3}$ Department of Radiotherapy and Experimental Cancerology, Ghent University, De Pintelaan 185, 9000 Gent, Belgium

${ }^{4}$ Analytical, Environmental and Geochemistry, Vrije Universiteit Brussel, Pleinlaan 2, 1050 Brussels, Belgium

Full list of author information is available at the end of the article
}

(c) The Author(s). 2021 Open Access This article is licensed under a Creative Commons Attribution 4.0 International License, which permits use, sharing, adaptation, distribution and reproduction in any medium or format, as long as you give appropriate credit to the original author(s) and the source, provide a link to the Creative Commons licence, and indicate if changes were made. The images or other third party material in this article are included in the article's Creative Commons licence, unless indicated otherwise in a credit line to the material. If material is not included in the article's Creative Commons licence and your intended use is not permitted by statutory regulation or exceeds the permitted use, you will need to obtain permission directly from the copyright holder. To view a copy of this licence, visit http://creativecommons.org/licenses/by/4.0/. The Creative Commons Public Domain Dedication waiver (http://creativecommons.org/publicdomain/zero/1.0/) applies to the data made available in this article, unless otherwise stated in a credit line to the data. 


\begin{abstract}
(Continued from previous page)
Conclusion: Our data confirm the observations that neurobehavioral development of young children is adversely influenced by environmental concentrations of PCBs, especially in boys. In this context, observation of play behaviour seems to be a reliable, easy to perform and sensitive test to detect neurotoxic effects of chemicals like PCB's and dioxin-like compounds in very young children. On the basis of our results, we hypothesize that an underarrousal pattern may play a role in the spectrum of effects measured in toddlers prenatally exposed to PCBs and dioxin-like compounds.
\end{abstract}

Keywords: Polychlorinated biphenyls (PCBs), P,p'-dichlorodiphenyldichloroethylene (DDE), Hexachlorobenzene (HCB), Dioxinlike substances, Cord blood, Mental development, Motor development, Play behaviour, Neutral (non-gender) behaviour

\section{Background}

PCBs (polychlorinated biphenyls) are classified as POPs (persistent organic pollutants) due to their very stable chemical structures and consequently very long half lives in the environment and living species, including humans [1]. Therefore the handling of PCBs has been strictly regulated in many countries for quite some time. Nevertheless, they will persist in many surroundings for some more decades and will stay a potential health hazard. Human exposure to PCBs is largely due to ingestion of contaminated foods, especially milk, fish and meat products. PCBs can cross the placenta causing prenatal exposure in the developing foetus and accumulates in breast milk. Literature suggests that compared to exposures later in life, foetuses and children are much more susceptible to the neurotoxic effects of PCB exposure, especially prenatally and possibly also in the first years of life [2]. The organochlorine pesticides $\mathrm{HCB}$ and DDE also are classified as persistent organic pollutants. and endocrine disruptors [3, 4]. Also animal data [5] have shown neurotoxic effects of PCB exposures. The neurotoxicity of PCBs may rest on many different mechanisms, including disruption of thyroid function, altering several neurotransmitter signalling pathways e.g. serotonergic, glutaminergic, GABA-ergic (dopaminergic and $\gamma$ aminobutyric acid) [4, 6-8]. Also, interference with intracellular $\mathrm{Ca}^{2+}$ dynamics may lead to altered dendritic arborisation and synaptogenesis [9].

Play behaviour (masculine/feminine) has been reported to change in children according to the level of prenatal PCB exposure, although in the opposite direction for boys and girls [10]. Gender specific effects might also occur with respect to cognition as higher exposed boys did worse on constructive tasks in the Yucheng study [11]. PCB's, and other endocrine disrupting substances can disrupt brain sexual differentiation and may affect brain development in a gender specific way $[12,13]$.

In this study, part of the Flemish Environmental Health Survey (2002-2006), we measured internal exposure in cord blood to PCBs, compounds with 'dioxinlike' activity, chlorinated pesticides [DDE and hexachlorobenzene $(\mathrm{HCB})$ and we also assessed IQ, behaviour, temperament and milestones in motor development up to 36 months of age. Much attention was paid to confounding factors including, amongst others, assessment of the environmental support, personality traits and intelligence of the mother.

We hypothesized that known effects on development and sex differences in effect were likely to occur and especially that gender specific play behavioural patterns would be influenced by prenatal exposure levels of PCB's and CALUX-TEQ.

\section{Methods \\ Study design and study population (participants)}

The study was set up as an observational prospective cohort study. Internal exposure of neonates was measured at birth using cord blood. At age 12, 24 and 36 months emotional and behavioural problems were assessed, and at 36 months a neurobehavioral evaluation of mother and child was performed.

Participants were recruited as part of an Flemish Environmental Health Survey (2002-2006) in Flanders. Between September 2002 and February 2004, motherchild pairs from the general population were recruited through 26 maternities which were selected by stratified sampling in eight study areas. The study areas included two urban areas (Antwerp and Ghent), an area characterized by fruit orchards, a rural area and four types of industrial areas (harbour, non-ferrous smelters, chemical industry and household waste incinerators). The selected areas contained $20 \%$ of the inhabitants of Flanders. Pregnant mothers could be included if they lived for at least five years in the area of interest, if they gave informed consent, and if they were able to fill out Dutch questionnaires. Participants in the neurobehavioral part of the study were recruited in the rural areas and in the areas around the harbours, the waste incinerators, and the areas near the non-ferrous smelters.

The study group was selected based on following inclusion criteria by the co-workers of the Provincial Institute of Hygiene -Antwerp: pregnancy without major complications (eclampsia, risk of imminent preterm birth), born at term, no major congenital abnormalities or diseases, no twins, no abnormal or asymmetrical reflexes during standard neurological screening during the 
first days and the children having only Dutch as their mother-tongue to prevent differences in language development. Informed consent was asked to participants whom were eligible in the sampled areas. At the end, 214 baby-mother pairs had given informed consent. Numbers were diminished because biomonitoring results could not be obtained in all participants (between $N=148$ CALUX-TEQ and $N=206$ DDE, see Table 2). One hundred and twenty nine pairs in which biomonitoring results were available, could be fully followed up until the age of 36 months $(60,3 \%)$. The number of participants in each analysis may be lower as not all tests could be completed in all children due to various factors (e.g. tiredness of the child, timing issues, cooperation of the child, failure of test systems).

\section{Blood sampling and measurements $P C B s$, Calux-TEQ, DDE, HCB}

Cord blood was aliquoted and plasma was separated by centrifugation within one day in either the maternity or blood bank laboratories. The aliquoted samples were kept in the refrigerator for maximal one week. Afterwards they were put at $-20^{\circ} \mathrm{C}$ until analysis. In cord plasma, marker polychlorinated biphenyls (PCB 138, 153 and 180), PCB 118 and 170 which may have more neurotoxic potentials, chlorinated pesticides [DDE and hexachlorobenzene $(\mathrm{HCB})]$, and dioxin-like compounds (CALUX ${ }^{\oplus}$ assay) were analysed. The PCBs and chlorinated pesticides were analysed by GC/ECD using the method of Gomara et al. [18]. The analyses were performed by two labs. Both laboratories participated in the AMAP proficiency testing scheme (Institute National de Santé Publique, Quebec, Canada). The measurement uncertainty (sum of systematic error and two times the reproducibility) was estimated from the results of the ClinChek and AMAP samples, and ranged between 21 and $34 \%$ for all the compounds except for HCB (64\%). The limit of detection for all chlorinated compounds was $0.02 \mu \mathrm{g} / \mathrm{L}$. Routinely measured cholesterol and triglycerides were used to express the results on a lipid weight basis [19]. Exposure to dioxin-like compounds was assessed via the CALUX ${ }^{\oplus}$ assay, based on in vitro activation of the aryl hydrocarbon receptor (AhR) of cultured H4IIE rat hepatoma cells by the dioxin-like compounds present in $5 \mathrm{~mL}$ cord plasma (BioDetection Systems BV, Amsterdam, The Netherlands). The extraction and clean-up procedures were performed as described by Koppen et al. [20]. The limit of detection was calculated as the light signal measured from the dimethyl sulfoxide-control plus 3 times its standard deviation on each well plate $(=16 \mathrm{pg}$ CALUX-TEQ/g cord plasma fat).

Lead $(\mathrm{Pb})$ and cadmium $(\mathrm{Cd})$ were measured in cord blood using standard clinical biological techniques.
General history, medical file data and general health questionnaires

\section{Before birth}

Shortly after birth/delivery, data regarding the child, data on life style of the parents and information about the current and former pregnancies were obtained through a general self-assessment questionnaire. These data and questionnaires were collected by trained staff members of the Provincial Institute for Hygiene and Epidemiology (V. Nelen). Women were asked whether they had had any infections, hypertension, diabetes or other diseases and/or complications during pregnancy $(0 / 1)$, whether they had used medication $(0 / 1)$, alcohol $(0 / 1)$ or drugs $(0 / 1)$, or had been smoking (0/1) during pregnancy. Almost all mothers reported to have taken some vitamin supplementation throughout their pregnancy.

\section{At birth}

Data regarding mother and child were also collected in the medical files of the hospital: data regarding the mother were medical history of the mother, weeks of pregnancy, complications during birth (0/1), age of the mother, congenital diseases $(0 / 1)$ and breastfeeding $(0 /$ $1)$. All children included were born at term ( $>36$ weeks). Data regarding the child were weight, length, Apgar scores, standard medical and neurological examination as performed by a specialized paediatrician. Two children had an asymmetrical Babinski sign, which were excluded. Four children had minor birth defects (a supplementary finger, a small skin-patch, minor dysplasia of the outer ears, one foot with moderate valgus malformation), which were considered as without significance. One child suffered from hydronephrosis and was excluded. All the other clinical signs were normal in all babies. After screening the files one baby was going to be raised in a foreign language and was excluded. In total, 202 mother-children pairs met all the inclusion criteria. If the Apgar score at the beginning $(1 \mathrm{~min})$ was 6 or less and/or other signs of foetal asphyxia were present (meconium stained amniotic fluid, aspiration, abnormal foetal heart rate, neonatal resuscitation) the baby was considered to have had perinatal asphyxia (0/1).

The first month (4-6 weeks after delivery) all mothers received a supplementary questionnaire. This questionnaire repeated and extended the questions used in the general questionnaire at birth as an extra control on the data. Semi-quantitative ethanol consumption (g ethanol/ week) was calculated.

\section{After birth}

In the first year the mothers filled out a monthly written questionnaire (by post) on child development, feeding, diseases of the child, imported life events, medication, smoking, alcohol or drug use of the mother. After the first year 
this was repeated every three months (by post) until at the age of 36 months the child was investigated. Additionally, important life events and stress factors were yearly questioned with the STAI (State-Trait Anxiety Inventory).

\section{Neurobehavioral test methods and neurobehavioral questionnaires}

An overview of the tests is shown in Tables 1, 2 and Fig. 1.

At the time the child reached the age of 12,24 and 36 months, the mother and pre-school playgroup teacher completed questionnaires regarding possible emotional and behavioural problems [Infant Behaviour Questionnaire (IBQ) [22]. The response rate of the IBQ at 24 months was too low to include the results of the analyses $(<40 \%)$.

At the time the child reached the age of 36 months, an appointment was made to carry out the neurobehavioral evaluation of mother and child and the HOME assessment (HOME, 1988).

All psychological tests and questionnaires used in this study are validated in Flanders for clinical use and are suitable for use in a research context. The NES (Neurobehavioral Evaluation System; [27]) was adapted according to the attentional task described by Patandin et al. [28] (catch the kitten). The tests were administered by trained test leaders with substantial experience in psychological testing of children and adults. The tests were divided over two test sessions and took place in a quiet room.

The Bayley Scales measure the mental and motor development and test behaviour of infants from one to fortytwo months of age. The scales have been used extensively worldwide to assess the development of infants. The examiner presents a series of test materials to the child and observes the child's responses and behaviours. The test contains items designed to identify young children at risk for developmental delay. In this study, mental en motor scales were assessed according to Van der Meulen et al. [21]. In the Mental scale, several types of abilities are evaluated: sensory/perceptual acuities, discriminations, and response; acquisition of object constancy; memory learning and problem solving; vocalization and beginning of verbal communication; basis of abstract thinking; habituation; mental mapping; complex language; and mathematical concept formation. In the Motor scale, the degree of body control, large muscle coordination, fine motor skills of the hands and fingers, dynamic movement, postural imitation, and the ability to recognize objects by sense of touch (stereo gnosis) were assessed.

Home Observation for Measurement of the Environment (HOME) is a descriptive profile which yields a systematic assessment of the caring environment in which the child is reared. The primary goal of the instrument is to measure, within a naturalistic context, the quality and quantity of stimulation and support available to a child in the home environment. Its focus is on the experience of the child in the home environment, the child as an active recipient of inputs from objects, events and transactions occurring in connection with the family surroundings $[14,15]$.

The Wechsler Abbreviated Scale of Intelligence (WASI, [16]) has been used in this study to obtain a reliable measure of intellectual ability of the mother. The WASI assessment provides traditional verbal, performance and full scale IQ scores.

A nominal STAI score was computed as a marker of prenatal stress [17]. The trait score of the STAI scale has proven to be stable across years, whereas the state score is more vulnerable to acute mood changes. Therefore a $0 / 1$ variable was created, based on the P90 of STAI trait score (measured at 12 months).

\section{Statistical analysis}

The relation between neurobehavioral development, including play behaviour, and the prenatal exposure levels of $\mathrm{PCB}$ and dioxin-like compounds, $\mathrm{DDE}, \mathrm{HCB}$ and interaction effects between the prenatal exposure levels of sum PCB and DDE or HCB were analysed in the total group and in boys and girls separately.

Database management and statistical analyses were performed with the SPSS program.

With ANCOVA analysis the difference between the different test-leaders (scoring and testing) was checked, using the same covariates as for the stepwise regression analysis (see below). No significant differences were found $(p>0,050)$ (multiple linear regression).

Correlation analysis of the covariates in our study group, showed that the highest education level of the parents was very highly correlated with the total IQ of the mother $\left(\mathrm{r}^{2}=.52 ; p<.001\right)$ and parity was highly correlated with the HOME score $\left(\mathrm{r}^{2}=.34 ; p<.05\right)$. Highest education level and parity were therefore not included in the regression analyses.

Stepwise regression was performed in the total group using the cord blood concentrations of the sum of the marker polychlorinated biphenyls PCBs 138, 153 and 180 (sum PCB), dioxin like substances measured with the Calux test, DDE and HCB as biomarkers of exposure. As covariates for the neurobehavioral test data and questionnaire results, we used total IQ of the mother (WASI), gender, mother's age at birth, smoking during pregnancy, alcohol use during pregnancy, neonatal asphyxia, medication use during pregnancy, infections or other interfering diseases during pregnancy, breastfeeding, STAI (trait, as a marker of prenatal stress), and total score of the HOME. Total IQ of the child (SON) was also taken into account for the stepwise multiple regression analyses of the questionnaire results. Stepwise regression analysis concerning gender-specific behaviour 
Table 1 Children: tests on behaviour, motor development, language skills, intelligence

\begin{tabular}{|c|c|c|c|}
\hline Questionnaires & Parameter & $\begin{array}{l}\text { Positive } \beta \text { indicates more or } \\
\text { better }\end{array}$ & $\begin{array}{l}\text { Age of } \\
\text { child }\end{array}$ \\
\hline $\begin{array}{l}\text { Bayley mental scale [21] } \\
\text { Bayley motor scale [21] }\end{array}$ & $\begin{array}{l}\text { Visual and auditory discernment, eye-hand coord- } \\
\text { ination, imitation, language development, memory }\end{array}$ & $\begin{array}{l}\text { Cognitive development } \\
\text { Motor development }\end{array}$ & $\begin{array}{l}36 \\
\text { mon }\end{array}$ \\
\hline
\end{tabular}

Bayley motor scale [21]

Infant Behaviour Questionnaire (IBQ) [22]: Temperament as observed by the mother

Milestones: developmental abilities

\section{Tests}

Reynell Language Developmental Scale (RTOS): receptive language development level measured by oral instructions to carry out small tasks while playing with toys [23].

Snijders-Oomen non-verbal intelligence test (SON 2.5-7), [24]: Intelligence: reasoning and visuospatial abilities

Observation of toy preference: 7 min. Lasting observation of masculine/feminine play behaviour $[25,26]$ and problem solving capacity. Mean score for the general population of 100 ( \pm SD 15$)$.

Motor development. Mean score for the general population of $100( \pm$ SD 15$)$

Scale 1 = stress and latency to approach sudden or Fear responses. 12 novel stimul

Scale 2 = smiling and laughter

Scale 3 = distress to limitations

Scale 4 = activity level

Scale $5=$ duration of orienting

$$
\begin{aligned}
& 1=\text { grasping } \\
& 2=\text { rolling over } \\
& 3=\text { sitting up } \\
& 4=\text { crawling } \\
& 5=\text { first steps alone }
\end{aligned}
$$

\section{Measurement type}

Verbal comprehension scale

Three intelligence quotients (IQ) can be calculated with this intelligence tests with a mean score for the general population of 100 ( \pm SD 15)

Total intelligence scale: $\mathrm{SON}-\mathrm{IQ}$

Performance Scale (PS) IQ

Reasoning Scale (RS) IQ

Masculine play behaviour

Feminine play behaviour

Non-gender specific play behaviour

Switching attention
Smiling or laughter from the child in general caretaking and play situations.

Persistence and goal oriented behaviour.

Gross motor activity: movement of arms and legs, squirming and locomotor activity. Habituation: more attention to and/or interaction with a single object for extended periods of time.

Time needed to achieve the milestone:

Grasping and picking up objects. Learning to flip over from his back to his tummy and vice versa. To sit up without support.

Crawling.

First steps alone unaided (first steps alone).

\section{Positive $\beta$ indicates a higher} capacity in terms of

Age of child

Receptive language development. months

(Nonverbal) intelligence (IQ). 36 Performance 10 : better in making months puzzles, mosaics and patterns. Reasoning IQ: better in categories, situations and analogies.

Time playing with masculine toys: little cars, fire truck, construction blocks, toy gun

Time playing with feminine toys: little dolls, hair doll, baby doll, kitchen accessories. Time playing with non-gender specific toys: puzzle, book The number of times the child switches between toys.

Computerised vigilance task adapted according to Patandin et al., [28].
0-36
36 months

36 months

(a)

Table 2 Mothers: Tests concerning caring environment, intelligence, anxiety

\begin{tabular}{lll}
\hline Tests & Measurement type & Time of assessment \\
\hline HOME [14, 15] & Home observation for measurement in the environment & 36 months \\
WASI [16] & Wechsler Abbreviated Scale of Intelligence & 36 months \\
STAI [17] & Trait and state anxiety measurement & 12 months \\
\hline
\end{tabular}




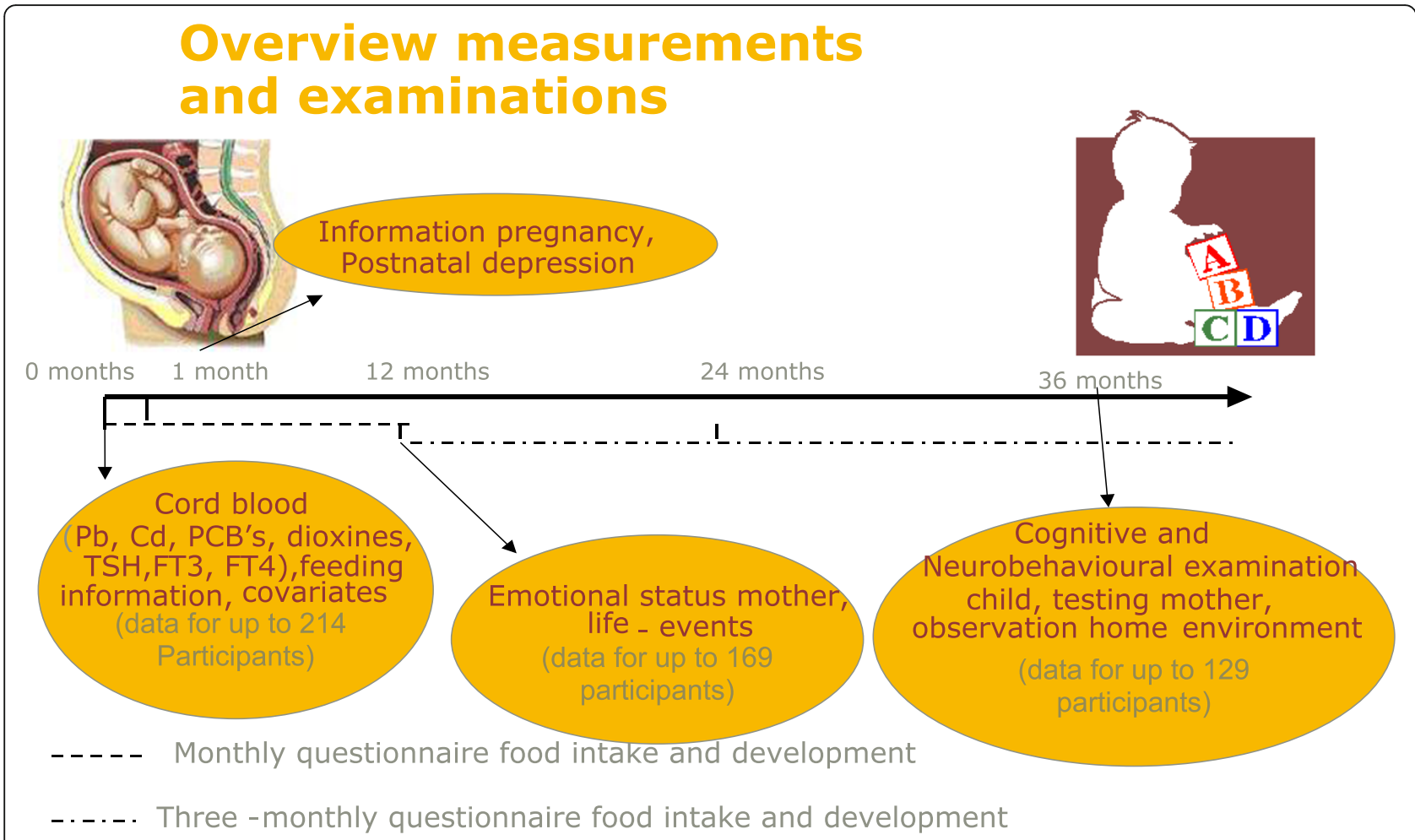

Fig. 1 Overview and timeline of the study

was done in the total group and in boys and girls separately. Gender specific results are only presented when statistically significant.

As group numbers differed over different tests, the number of subject is mentioned in every analysis.

In order to look at possible interaction and/or addition effects, the test and scale scores were transformed into standardised (z) scores. All potential factors were brought into the model (stepwise Multiple Linear Regression).

\section{Results}

\section{Personal characteristics and measured parameters of participants}

The personal characteristics and the data concerning measured parameters for all of the participants are summarized in Tables 3 and 4. No significant differences were noted in organochlorine cord blood concentrations between boys and girls (see supplementary material Table 1). No correlation was found between the organochlorines and the other parameters mentioned in Tables 3 and 4, except for a negative correlation of $\mathrm{Pb}$ with HCB ( $\mathrm{r} 2=-0,146, p=0,045)$, and Pb with Calux-TEQ $(\mathrm{r} 2=-0,191, \mathrm{p}=0,025)$.

\section{Description of neurobehavioral characteristics}

Observed neurobehavioral characteristics are summarized in Table 5 .
There was no significant difference in any of the neurobehavioral outcome variables regarding the different regions $(p>0,050)$ (multiple linear regression).

\section{Associations with neurobehavioral characteristics using questionnaires}

Associations with neurobehavioral characteristics measured using questionnaires are summarized in Table 6.

In boys and girls together higher CALUX-TEQ and DDE values were associated with a decrease in stress and latency to approach sudden or novel stimuli (scale1), $\mathrm{HCB}$ was associated with an increase in smiling and laughter (scale 2) and PCB-118 was associated with a decrease in distress to limitations (scale 3).

In girls, DDE was associated with a decrease in stress and latency to approach sudden or novel stimuli (scale 1) and a decrease duration of orienting (scale 5), and CALUX-TEQ and HCB were, contrary to DDE, associated with an increase in duration of orienting (scale 5).

In boys, higher internal exposure levels to $\mathrm{HCB}$, DDE and the factor sum PCB*DDE were associated with an increase in smiling and laughter (scale 2), and PCB 118 was associated with an increase in distress to limitations. Interestingly, different significant associations between internal exposure to organochlorine compounds and temperament as observed by the mother were observed for boys and girls. 
Table 3 Characteristics and exposure of partcipants

\begin{tabular}{llllll}
\hline $\begin{array}{l}\text { Total group } \\
\boldsymbol{N}=\mathbf{2 1 4}\end{array}$ & $\mathbf{N}$ & Mean & Minimum & Maximum & Std. Deviation \\
\hline HOME & 127 & 47,7 & 28 & 55 & 4,3 \\
Parity & 206 & 1,6 & 1,0 & 4,0 & 0,8 \\
Total IQ mother (WASI) & 129 & 103,9 & 75 & 6 & 12,1 \\
Highest education level of both parents & 206 & 4,3 & 0 & 41,6 & 1,3 \\
Age of mother at birth & 206 & 29,5 & 20,3 & 20,6 & 3,9 \\
BMI child at birth & 206 & 13,6 & 9,8 & 150 & 1,4 \\
SON, Total IQ-scale & 125 & 113,7 & 70 & 1 & 13,6 \\
Total STAl & 169 & 0,1 & 0 & 305,6 & 0,4 \\
Sum PCB ng/g total lipid * & 198 & 87,9 & 2,8 & 71,1 & 59,6 \\
PCB 118 ng /g total lipid & 198 & 14,9 & 0 & 55,6 & 11,3 \\
PCB 170 ng/g total lipid & 197 & 8,9 & 0 & 130,2 & 7,4 \\
Calux-TEQ pg/g total lipid & 148 & 30,1 & 5,1 & 1274,5 & 20,5 \\
DDE ng/g total lipid & 206 & 198,2 & 8,2 & 132,1 & 193,5 \\
HCB ng/g total lipid & 197 & 27,8 & 2,4 & 87.3 & 20,4 \\
Lead $\mu$ g/L & 201 & 19.2 & 1.0 & 13.9 & 15.8 \\
Cadmium $\mu$ g/L & 201 & 0.7 & 0.1 & 1.1
\end{tabular}

HOME, WASI, SON total IQ-scale, Total STAl: see overview tests in Tables 1 and 2

Sum PCB, PCB 118, PCB 170, Calux-TEQ, DDE-conc., HCB-conc.: see "Blood sampling and measurements"

*Sum PCB $=$ PCB 138+ PCB 153+ PCB 180

\section{Associations with differences in milestones}

Associations with differences in milestones are summarized in Table 7.

In the first 36 months (girls and boys together), increasing levels of sum PCB as well as increasing levels of individual PCBs (PCB118, PCB 170) and of HCB were associated with a significant later onset of first steps alone. The interaction between PCBs and pesticides was not only associated with a delay in the first steps, but was also associated with a delay in the age of crawling. In boys only, earlier grasping and earlier rolling over tended to be associated with sum PCB (Table 7). In girls sum $\mathrm{PCB}^{*} \mathrm{DDE}$ tended to be associated with earlier grasping. CALUX-TEQ was not associated with a negative effect on milestones in the total group. Higher DDE concentrations were significantly associated with delayed first steps alone in boys. Both in boys and in the total group a significant association was found between higher prenatal DDE concentrations and ability to sit up earlier.

Effects seem to be more pronounced in boys than in girls, except that in girls delayed crawling showed a positive association with the interaction of sum $\mathrm{PCB} * \mathrm{HCB}$ and that the ability to grasp showed a positive association with higher sum $\mathrm{PCB} * \mathrm{DDE}$.

\section{Cognitive tests and behavioural observations}

Associations with differences in cognitive tests are summarized in Table 8.

At 36 months, increasing levels of sum $\mathrm{PCB}$ as well as increasing levels of individual PCBs (PCB118, PCB 170) and CALUX-TEQ were associated with significant lower performance on language development (RTOS). Compared to the lowest sum PCB exposed children, the highest exposed children had RTOS scores that were 38\% lower. Increasing concentrations

Table 4 Gender, events during pregnancy and at birth $(\mathrm{N}=214)$

\begin{tabular}{lll}
\hline & Number (\%) & $\begin{array}{c}\text { Missing data } \\
\text { Number (\%) }\end{array}$ \\
\hline Boys & $107(50,0 \%)$ & 0 \\
Breastfeeding (0/1) & $70 / 130(33,0 \% / 61,3 \%)$ & $12(5,7 \%)$ \\
Smoked during pregnancy (0/1) & $185 / 25(87,3 \% / 11,8 \%)$ & $2(0,9 \%)$ \\
Alcohol use during pregnancy (0/1) & $197 / 15(92 \% / 7,1 \%)$ & $2(0,9 \%)$ \\
Asphyxia baby (0/1) & $189 / 23(89,2 \% / 10,8 \%)$ & 0 \\
\hline
\end{tabular}


Table 5 Descriptive results: behaviour, motor development, language skills, intelligence

\begin{tabular}{|c|c|c|c|c|c|c|c|}
\hline & \multicolumn{2}{|l|}{$\mathbf{N}$} & \multirow[t]{2}{*}{ Mean } & \multirow[t]{2}{*}{ Median } & \multirow{2}{*}{$\begin{array}{l}\text { Std. } \\
\text { Deviation }\end{array}$} & \multirow[t]{2}{*}{ Minimum } & \multirow[t]{2}{*}{ Maximum } \\
\hline & Valid & Missing & & & & & \\
\hline Bayley Scales of infant Development II NL: Mental Scale Index score & 112 & 102 & $\begin{array}{l}109, \\
51\end{array}$ & 108,00 & 15,14 & 69 & 163 \\
\hline Bayley Scales of infant Development II NL: Motor Scale index score & 93 & 121 & $\begin{array}{l}101 \\
97\end{array}$ & 101,00 & 12,78 & 79 & 137 \\
\hline Snijders-Oomen Non-Verbal Intelligence test: Performance Scale & 125 & 89 & $\begin{array}{l}108, \\
66\end{array}$ & 110,00 & 15,92 & 67 & 148 \\
\hline Snijders-Oomen Non-Verbal Intelligence test: Reasoning Scale & 125 & 89 & $\begin{array}{l}115 \\
13\end{array}$ & 115,00 & 12,50 & 66 & 150 \\
\hline Snijders-Oomen Non-Verbal Intelligence test: Total Scale & 125 & 89 & $\begin{array}{l}113, \\
72\end{array}$ & 114,00 & 13,59 & 70 & 150 \\
\hline $\begin{array}{l}\text { Reynell Language Development Scale: Language Development Total score } \\
\text { (language comprehension) }\end{array}$ & 101 & 113 & $\begin{array}{l}102, \\
80\end{array}$ & 104,00 & 17,82 & 59 & 142 \\
\hline milestones: smiling (months) & 176 & 38 & 1,44 & 1,00 & 1,01 & 1 & 9 \\
\hline milestones: reach for and take a toy (months) & 180 & 34 & 2,91 & 3,00 & 1,19 & 1 & 8 \\
\hline milestones: rolling over (months) & 156 & 58 & 5,30 & 5,00 & 1,66 & 1 & 10 \\
\hline milestones: sit up straight (months) & 154 & 60 & 7,29 & 7,00 & 1,44 & 4 & 15 \\
\hline milestones: crawling (months) & 130 & 84 & 9,25 & 9,00 & 2,15 & 4 & 21 \\
\hline Milestones: first steps alone & 69 & 145 & 13,06 & 14,00 & 2,57 & 8 & 20 \\
\hline IBQ 12 mths: Stress and Latency to Approach Sudden or Novel Stimuli & 151 & 63 & 2,81 & 2,81 &, 81 & 1,20 & 4,58 \\
\hline IBQ 12 mths: Smiling and Laughter & 151 & 63 & 5,41 & 5,47 &, 74 & 3,36 & 7,00 \\
\hline IBQ 12 mths: Distress to Limitations & 151 & 63 & 3,04 & 3,00 & $, 70,412$ & 1,33 & 5,05 \\
\hline IBQ 12 mths: Activity Level & 151 & 63 & 3,32 & 3,29 &, 88 & 1,24 & 5,47 \\
\hline IBQ 12 mths: Duration of Orienting & 150 & 64 & 3,41 & 3,41 & 947 & 1,36 & 6,29 \\
\hline Masculine play behaviour (\%) & 100 & 114 & 43,68 & 37,67 & 31,08 & 0,00 & 100,00 \\
\hline Feminine play behaviour (\%) & 100 & 114 & 41,51 & 36,99 & 30,39 & 0,00 & 100,00 \\
\hline Non-gender specific play behaviour (\%) & 100 & 114 & 14,81 & 9,61 & 18,31 & 0,00 & 94,00 \\
\hline
\end{tabular}

of $\mathrm{HCB}$ and higher values for the interaction between PCB and pesticides were associated with the same effect. One of the neurotoxic compounds, PCB118, was associated with a significant deterioration, in boys only, of reasoning (SON-RS IQ), performance (SONPS IQ) and total IQ (SON-TIQ). The interaction factor sum $\mathrm{PCB} * \mathrm{HCB}$ may have an additive effect. DDE does not seem to be associated with an adverse effect, except in interaction with sum PCB (Table 8), possibly suggesting a synergistic effect.

The NES results were not analysed (see discussion).

\section{Associations with observed differences in play behaviour} Associations with observed differences in behaviour are summarized in Table 9.

In the toy preference task at 36 months, several significant associations were observed for as well girls as boys. Higher sum PCB exposed children alternate less between toys. They play more with a puzzle or book (non-gender specific play behaviour) compared to children with lower prenatal sum PCB-levels and they display less masculine play behaviour. An increase in concentration of sum PCB of $58,82 \mathrm{ng} / \mathrm{g}$ lipids is associated with one time less switching between toys during $7 \mathrm{~min}$. Considering the observed range of sum PCB (2,81 till 305,56 ng/g lipids) the highest exposed child switches toys almost once per minute less compared to the lowest exposed child. Switching in this case means also crawling, first steps alone and turning, as toys were displayed in a semicircle. PCB 118 exposure was associated with a decrease in masculine play behaviour in as well girls as boys. $\mathrm{PCB}$ 17 exposure was associated with an increase in nongender specific play behaviour in as well girls as boys.

As to significant association observed only in girls, CALUX-TEQ exposure was associated with an increase in non-gender specific play behaviour.

As to significant associations observed only in boys, PCB118 exposure was associated with an increase in non-gender specific play behaviour, and a decrease in switching between toys. PCB 170 exposure was associated with a decrease in masculine play behaviour. $\mathrm{HCB}$ exposure was associated with a decrease in masculine 
Table 6 Associations between exposure and behaviour assessed through IBQ (beta coefficients)

\begin{tabular}{|c|c|c|c|c|c|c|}
\hline \multirow[t]{2}{*}{ IBQ } & \multicolumn{6}{|c|}{12 months } \\
\hline & $\mathrm{N}$ & $\begin{array}{l}\text { scale } 1 \\
\text { (stress) }\end{array}$ & $\begin{array}{l}\text { scale } 2 \\
\text { (smiling and laughter) }\end{array}$ & $\begin{array}{l}\text { scale } 3 \\
\text { (distress to limitations) }\end{array}$ & $\begin{array}{l}\text { scale } 4 \\
\text { (activity) }\end{array}$ & $\begin{array}{l}\text { scale } 5 \\
\text { (duration of orienting) }\end{array}$ \\
\hline Sum PCB ng/g lipid & $T=96$ & -.081 & -.164 & .014 & .047 & -0.125 \\
\hline Girls & $q=44$ & NS & NS & NS & NS & NS \\
\hline Boys & $\hat{o}=52$ & NS & NS & NS & NS & NS \\
\hline Calux-TEQ pg/g lipid & $T=68$ & $-.247^{*}$ & .117 & .048 & .119 & .085 \\
\hline Girls & $q=37$ & NS & NS & NS & NS & $0.468^{* *}$ \\
\hline Boys & $\hat{\delta}=31$ & NS & NS & NS & NS & NS \\
\hline PCB-118 ng/g lipid & $\mathrm{T}=95$ & -.092 & .007 & $-.201 *$ & -.131 & -.061 \\
\hline Girls & $q=51$ & NS & NS & NS & NS & NS \\
\hline Boys & $\hat{\delta}=44$ & NS & NS & $-0.379^{*}$ & NS & NS \\
\hline PCB-170 ng/g lipid & $T=95$ & .007 & .187 & -.103 & -.054 & -.083 \\
\hline Girls & $q=51$ & NS & NS & NS & NS & NS \\
\hline Boys & $\delta=44$ & NS & NS & NS & NS & NS \\
\hline HCB ng/g lipid & $T=93$ & -.150 & $.193^{*}$ & -.022 & .045 & .182 \\
\hline Girls & $q=50$ & NS & NS & NS & NS & $0.343^{*}$ \\
\hline Boys & $\hat{o}=43$ & NS & $0.386^{*}$ & NS & NS & NS \\
\hline DDE ng/g lipid & $T=100$ & $-.201 *$ & .071 & -.147 & .103 & -.158 \\
\hline Girls & $q=54$ & $-0.299 *$ & NS & NS & NS & $-0.308^{*}$ \\
\hline Boys & $\hat{o}=46$ & NS & $0.347^{*}$ & NS & NS & NS \\
\hline Sum $P C B^{*} H C B$ & $T=93$ & -.079 & -.046 & -.048 & -.034 & .031 \\
\hline Girls & $q=50$ & NS & NS & NS & NS & NS \\
\hline Boys & $\hat{\jmath}=43$ & NS & NS & NS & NS & NS \\
\hline Sum PCB*DDE & $T=96$ & .026 & .078 & .054 & .159 & .078 \\
\hline Girls & $q=52$ & NS & NS & NS & NS & NS \\
\hline Boys & $\hat{\delta}=44$ & NS & $0.376^{*}$ & NS & NS & NS \\
\hline
\end{tabular}

IBQ and IBQ scales: see overview tests in Table 1

PCBs, Calux-TEQ, DDE, HCB: see blood sampling and measurements

Su PCB*HCB, sum $P C B * D D E$ : see statistical analysis

${ }^{*}=0.050 \leq p<0.10,{ }^{* *}=0.010 \leq p<0.050,{ }^{* *}=0.001 \leq p<0.010$

play behaviour and with an increase in non-gender specific play behaviour. DDE exposure was associated with a decrease in masculine play behaviour.

As to the effect of siblings on the play behaviour of the tested children, we noted that 13 of the boys had a sister, and 12 of the girls had a brother. As can be seen from supplementary material Table 3, having a sister did not weaken the associations between internal exposure and play behaviour in boys. Neither did having a brother weaken the associations between internal exposure and play behaviour in girls as shown in supplementary material Table 4.

As can be seen from Table 9, observed associations were more pronounced in boys than in girls. In boys, sum $\mathrm{PCB}$ exposure was associated with a more pronounced diminishment in switching behaviour compared to boys and girls considered together. An increase of $37,04 \mathrm{ng} / \mathrm{g}$ lipids in the sum PCB levels is associated with 1 switch between toys less per $7 \mathrm{~min}, 64 \%$ less playing time with boys-specific toys and $62 \%$ more with non-gender specific toys.

\section{Discussion}

Limitations of this study include the fact that the neurological examination at the time of birth, performed by a specialized pediatrician, was not performed by certified researchers. Also, although the children were examined at 36 months by specialized clinical psychologists, no complete medical assessment nor school results were available at the end of the study. As the Flemish Agency for Mental Health involved in the Study closed down many years ago and that many documents and computer files got lost, some details of the statistical models used are not available any more. 
Table 7 Associations between exposure and motor development in terms of milestones (beta coefficients)

\begin{tabular}{|c|c|c|c|c|c|}
\hline \multicolumn{6}{|l|}{ Milestonesss } \\
\hline Total Group & $\begin{array}{l}\text { Grasping } \\
\mathbf{T}=109 \\
q=56 \\
\hat{\gamma}=53\end{array}$ & $\begin{array}{l}\text { rolling } \\
\text { over } \\
\mathbf{T}=98 \\
q=50 \\
+=48\end{array}$ & $\begin{array}{l}\text { sitting } \\
\text { up } \\
\mathrm{T}=99 \\
+=50 \\
+=49\end{array}$ & $\begin{array}{l}\text { Crawling } \\
\mathbf{T}=46 \\
+=28 \\
+\hat{O}=18\end{array}$ & $\begin{array}{l}\text { First steps } \\
\text { alone } \\
\mathbf{T}=46 \\
O=28 \\
+=18\end{array}$ \\
\hline $\begin{array}{l}\text { Sum PCB ng/ } \\
\text { g lipid }\end{array}$ & -.178 & .020 & .212 & .230 & $.338^{* *}$ \\
\hline Girls & NS & NS & NS & NS & NS \\
\hline Boys & $-.371^{*}$ & $-.427^{*}$ & NS & NS & NS \\
\hline $\begin{array}{l}\text { Calux-TEQ } \\
\mathrm{pg} / \mathrm{g} \text { lipid }\end{array}$ & .043 & -.015 & .015 & .145 & .078 \\
\hline Girls & NS & NS & NS & NS & NS \\
\hline Boys & NS & NS & NS & NS & NS \\
\hline $\begin{array}{l}\text { PCB-118 ng/g } \\
\text { lipid }\end{array}$ & .013 & -.090 & -.064 & -.016 & $.451^{* * *}$ \\
\hline Girls & NS & NS & NS & NS & NS \\
\hline Boys & NS & NS & NS & NS & $.577^{* *}$ \\
\hline $\begin{array}{l}\text { PCB-170 ng/g } \\
\text { lipid }\end{array}$ & -.081 & -.043 & .049 & .193 & $.366^{* *}$ \\
\hline Girls & NS & NS & NS & NS & NS \\
\hline Boys & NS & NS & NS & NS & $.378^{*}$ \\
\hline $\begin{array}{l}\text { HCB ng/g } \\
\text { lipid }\end{array}$ & .049 & .039 & .049 & .175 & $.330 * *$ \\
\hline Girls & NS & NS & NS & NS & NS \\
\hline Boys & NS & NS & NS & NS & $.450^{*}$ \\
\hline $\begin{array}{l}\text { DDE ng/g } \\
\text { lipid }\end{array}$ & .082 & .019 & $-.260 * * *$ & .028 & .119 \\
\hline Girls & NS & NS & NS & NS & NS \\
\hline Boys & NS & NS & $-.296^{*}$ & NS & $.642 * *$ \\
\hline Sum $P C B^{*} H C B$ & -.065 & -.101 & -.032 & $.278^{* *}$ & $.463^{* * *}$ \\
\hline Girls & NS & NS & NS & $.327^{*}$ & NS \\
\hline Boys & NS & NS & NS & NS & $.538^{* *}$ \\
\hline $\begin{array}{l}\text { Sum } \\
\text { PCB*DDE }\end{array}$ & -.183 & -.077 & -.163 & $.279 *$ & $.343^{* *}$ \\
\hline Girls & $-.312^{*}$ & NS & NS & NS & NS \\
\hline Boys & NS & NS & NS & NS & $.630^{* *}$ \\
\hline
\end{tabular}

Milestones: see overview tests in Table 1

PCBs, Calux-TEQ, DDE, HCB: see blood sampling and measurements Sum $P C B * H C B$, sum $P C B * D D E$ : see statistical analysis

${ }^{*}=0.050 \leq \mathrm{p}<0.10,{ }^{* *}=0.010 \leq \mathrm{p}<0.050,{ }^{* * *}=0.001 \leq \mathrm{p}<0.010$

In this older cohort (2002-2004), representative for the Dutch speaking Flemish population, attention was paid to controlling for confounding factors, although not all confounding factors could be taken into consideration (e.g. the possible influence of air pollution on brain function) [29]. Analyses did not indicate bias by co-exposure of $\mathrm{Pb}$ and $\mathrm{Cd}$, which were measured as ubiquitous neurotoxic environmental polluting metals in cord blood.
Comparing the exposure levels in our study with other studies is not straightforward because different parameters are measured in the different studies, and because different ratios were observed between maternal serum concentrations and cord serum concentrations. We made a tentative comparison summarized in supplementary material Table 2, which indicates that the internal exposure to PCBs in our study is situated in a middle range of internal exposures measured in other studies on general populations [28, 30-42], and is more than 20 times lower than in the Yucheng incident in Taiwan [42].

The results of all neurobehavioral tests and questionnaires are described extensively and are consistent with neurobehavioral effects reported before (2, review). Compared to the lowest exposed children, the highest exposed children had language comprehension scores (RTOS) that were $38 \%$ lower. One of the neurotoxic compounds, PCB118, was associated with a significant deterioration, in boys only, of reasoning (SON-RS IQ), performance (SON-PS IQ) and total IQ (SON-TIQ.

Our results resemble those reported by Rogan et al. [34], Boucher et al. [43], Berghuis et al. [31] in which it was shown that first milestones may be reached earlier (grasping, rolling over) but later milestones (first steps alone) may be delayed with higher prenatal exposures to PCBs and dioxin-like compounds. These both effects seem to be more pronounced in boys compared to girls (sum $\mathrm{PCB}$, sum $\mathrm{PCB} * \mathrm{HCB}$, sum PCB*DDE, DDE, PCB118, PCB170).

The milestones like crawling and first steps alone are markers of motor development requiring balance and coordination, but also requiring active behaviour. Active motor behaviour is one of the six elements of temperament [44]. We measured temperament at 12 months of age as a basic characteristic of behaviour by the IBQ. Temperament is described to be influenced by heredity, maturation and experience $[45,46]$ but may also be influenced by prenatal toxic factors e.g. parental smoking [47]. Effects on temperament related to PCBs or dioxinlike compounds have not been frequently reported in toddlers [2]. Our results reported in Table 6. suggest that prenatal exposure to these endocrine disruptors might result in less distressed children. This could result in gradually less reactive children to stimuli and possibly underarousal patterns in higher exposed children [45]. Our results seem to be similar to those of Jacobson et al. [48], showing a rather reduced activity in 4-year old children associated with higher PCB levels.

We observed a less masculine, more non-gender specific, less active play behaviour with less switching between toys in association with PCB exposure, which was more pronounced in boys. An underarousal pattern may explain this observed reduced play activity as well as the observations made in terms of the milestones and IBQ. 
Table 8 Associations between exposure and cognitive functioning (beta coefficients)

\begin{tabular}{|c|c|c|c|c|c|}
\hline \multicolumn{6}{|l|}{ Cognitive tests } \\
\hline & $N$ & $\begin{array}{l}\text { RTOS } \\
\text { (language development) } \\
\begin{aligned} T=97 \\
0=50 \\
+ \\
\hat{O}=47\end{aligned}\end{array}$ & $\begin{array}{l}\text { SON-RS IQ } \\
\text { (Reasoning) } \\
T=125 \\
+=62 \\
O=63\end{array}$ & $\begin{array}{l}\text { SON-PS IQ } \\
\text { (performance) } \\
T=125 \\
O=62 \\
+=63\end{array}$ & $\begin{array}{l}\text { SON-TIQ } \\
\text { (total intelligence) } \\
T=125 \\
0=62 \\
+\hat{O}=63\end{array}$ \\
\hline Sum PCB ng/g lipid & 99 & $-.103^{* *}$ & -.036 & -.054 & -.043 \\
\hline Girls & & NS & NS & NS & NS \\
\hline Boys & & NS & NS & NS & NS \\
\hline Calux-TEQ pg/g lipid & 60 & $-.267^{* *}$ & -.002 & -.042 & -.010 \\
\hline Girls & & NS & NS & NS & NS \\
\hline Boys & & NS & NS & NS & NS \\
\hline PCB-118 ng/g lipid & 99 & $-.125^{*}$ & NS & NS & NS \\
\hline Girls & & NS & NS & NS & NS \\
\hline Boys & & NS & $-.353^{* *}$ & $-.401 * * *$ & $-.424^{* * *}$ \\
\hline PCB-170 ng/g lipid & 98 & $-.243^{* *}$ & -.050 & -.107 & -.083 \\
\hline Girls & & NS & NS & NS & NS \\
\hline Boys & & NS & NS & NS & NS \\
\hline HCB ng/g lipid & 98 & $-.262^{* *}$ & -.212 & -.055 & -.147 \\
\hline Girls & & NS & NS & NS & NS \\
\hline Boys & & NS & NS & NS & NS \\
\hline DDE ng/g lipid & 79 & -.028 & .052 & -.009 & .026 \\
\hline Girls & & NS & NS & NS & NS \\
\hline Boys & & NS & NS & NS & NS \\
\hline Sum $P C B^{*} H C B$ & 97 & $-.327^{* * *}$ & -.168 & -.072 & -.121 \\
\hline Girls & & NS & NS & NS & NS \\
\hline Boys & & NS & NS & NS & NS \\
\hline Sum PCB*DDE & 79 & $-.245^{* *}$ & -.048 & .045 & -.010 \\
\hline Girls & & NS & NS & NS & NS \\
\hline Boys & & NS & NS & NS & NS \\
\hline
\end{tabular}

RTOS, SON-RS IQ, SON-PS IQ, SON-TIQ: see overview tests in Table 1

PCBs, Calux-TEQ, DDE, HCB: see blood sampling and measurements

Sum $P C B * H C B$, sum $P C B^{*} D D E$ : see statistical analysis

${ }^{*}=0.050 \leq \mathrm{p}<0.10,{ }^{* *}=0.010 \leq \mathrm{p}<0.050,{ }^{* * *}=0.001 \leq \mathrm{p}<0.010$

Vreugdenhil et al. [10] also found a less masculinised play behaviour, although it was not statistically significant, and although in girls postnatal PCB exposure through breastmilk was positively related to more masculine play behaviour. Vreugdenhil et al. [10] used the PSAI questionnaire to measure sex linked play behaviour, which has some drawbacks [49]. In contrast to the PSAI, our experience with the Observation of Toy Preference is that this test is an easy to applicate, easy to interpret, parent independent measurement of gender-specific behaviour, with a high (0.99) inter-observer reliability.

Patandin et al. [38] described a play behavioural test with high and low level play episodes. High level play, number of episodes of non-play behaviour and period of time at non-play behaviour were significantly diminished in association with prenatal exposure to PCBs. Although the measurements are not totally comparable, they both measure adequate play behaviour which seems to be diminished in our and Patandin's group. If this is a result of attentional deficit or due to reduced activity is a matter of debate [28, 48]. Patandin [28] did not found a relation between cord blood PCB concentrations and most attentional parameters (mean reaction time, slope of reaction time, Groninger Behaviour Observation Scale parents questionnaire) in 42 months old children, but measuring attention may not be valid under 4.5 years [50]. We tried to measure attention in 36 month old children by a test described by Jacobson et al. [51] and used by Patandin [28] and Stewart [52]. The frame of the continuous performance test of the NES3 was used to develop a test which might be feasible for 3 year old children. We noticed that most children didn't complete 
Table 9 Associations between exposure and play behaviour (beta coefficients)

\begin{tabular}{|c|c|c|c|c|c|c|c|c|c|}
\hline & & Girls & & & & Boys & & & \\
\hline & $\begin{array}{l}\text { girls/ } \\
\text { boys } \\
\mathrm{N}\end{array}$ & $\begin{array}{l}\text { masculine } \\
\text { play } \\
\text { behaviour }\end{array}$ & $\begin{array}{l}\text { feminine } \\
\text { play } \\
\text { behavior }\end{array}$ & $\begin{array}{l}\text { non-gender } \\
\text { specific play } \\
\text { behaviour }\end{array}$ & $\begin{array}{l}\text { switching } \\
\text { attention }\end{array}$ & $\begin{array}{l}\text { masculine } \\
\text { play } \\
\text { behaviour }\end{array}$ & $\begin{array}{l}\text { feminine } \\
\text { play } \\
\text { behaviour }\end{array}$ & $\begin{array}{l}\text { non-gender } \\
\text { specific play } \\
\text { behaviour }\end{array}$ & $\begin{array}{l}\text { switching } \\
\text { attention }\end{array}$ \\
\hline $\begin{array}{l}\text { Sum PCB } \\
\text { ng/g lipid }\end{array}$ & $47 / 37$ & $-.247^{*}$ & -.121 & $.250 *$ & $-.342^{* *}$ & $-.269^{*}$ & -.002 & $.266^{*}$ & $-.383^{* *}$ \\
\hline $\begin{array}{l}\text { Calux-TEQ } \\
\mathrm{pg} / \mathrm{g} \text { lipid }\end{array}$ & $47 / 37$ & -.010 & -.162 & $.313^{*}$ & .126 & -.199 & .257 & .014 & -.244 \\
\hline $\begin{array}{l}\text { PCB-118 } \\
\text { ng/g lipid }\end{array}$ & $45 / 39$ & $-.313^{* *}$ & .202 & .052 & .273 & $-.326^{* *}$ & -.087 & $.361^{* *}$ & $-.325^{* *}$ \\
\hline $\begin{array}{l}\text { PCB-170 } \\
\text { ng/g lipid }\end{array}$ & $47 / 37$ & -.031 & -.181 & $.314^{* *}$ & -.035 & $-.286^{*}$ & -.096 & $.278^{*}$ & .091 \\
\hline $\begin{array}{l}\text { HCB ng/g } \\
\text { lipid }\end{array}$ & $51 / 43$ & -.066 & .114 & -.100 & -.091 & $-.374^{* *}$ & -.027 & $.363^{* *}$ & -.163 \\
\hline $\begin{array}{l}\text { DDE ng/g } \\
\text { lipid }\end{array}$ & $53 / 43$ & .307 & -.248 & -.047 & -.041 & $-.331^{* *}$ & .228 & .145 & -.006 \\
\hline $\begin{array}{l}\text { Sum } \\
\text { PCB*HCB }\end{array}$ & $47 / 37$ & .066 & -.101 & .075 & .081 & -.079 & .056 & .051 & -.106 \\
\hline $\begin{array}{l}\text { Sum } \\
P C B^{*} D D E\end{array}$ & $47 / 37$ & .103 & -.121 & .054 & -.031 & .146 & -.034 & -.166 & .161 \\
\hline
\end{tabular}

Play behaviour: see overview tests in Table 1

$P C B s$, Calux-TEQ, DDE, HCB: see blood sampling and measurements

Sum $P C B^{*} H C B$, sum $P C B * D D E$ : see statistical analysis

${ }^{*}=0.050 \leq p<0.10,{ }^{* *}=0.010 \leq p<0.050,{ }^{* * *}=0.001 \leq p<0.010$

the test (not fully validated in children of this age), probably because sustained attention cannot be reliably measured at this age (results not reported). However, diminished attention related to perinatal $\mathrm{PCB}$ exposures are frequently reported in older children ( $>4$ years) [2].

In contrast to others, we didn't find any influence of breastfeeding [53-55].

Sex-linked differences as reported here, in other human studies [10, 11, 56-58] and in animal studies [59-62] might result from oestrogenic and anti-oestrogenic actions $[4,63$, 64] as oestrogens are essential in the neurogenesis and functionality of neurons which are important in learning processes and behaviour such as anxious and genderspecific behaviour $[5,65]$. In mammalians, the ontogenetic evolution towards the female phenotype appears in some way to be the default process and occurs to a large extent without sex hormone influence [12], while even small differences in levels and timing of exposure to hormones or endocrine disruptors may disrupt brain sexual differentiation [12]. The group of Andrea Gore showed in rats that PCBs cause changes in sexually-dimorphic social interactions and communications and that these changes were associated with (and probably rested on) modifications of gene expression in the medial preoptic nucleus, part of the social decision-making network in the brain. In females PCBs changed expression of several steroid hormone receptor and neuropeptide genes, whereas in males only one gene (the circadian gene Per2) was affected, although more behavioral changes were observed in males [66]. Even adult males and females do not necessarily react in the same way to exogenous substances. In the Flemish biomonitoring, changes in gene expression associated with internal exposure to DDE, hexachlorobenzene, marker PCBs and dioxinlike activity were predominantly in opposite direction for men and women [67].

\section{Conclusion}

Our data confirm the observations that neurobehavioral development of young children is adversely influenced by environmental concentrations of organochlorine pollutants, especially in boys. Motor development, playing activity and cognitive development tend to be delayed or diminished. We found observation of play behaviour to be a reliable, easy to perform and sensitive test to detect neurotoxic effects of chemicals like PCB's and dioxin-like compounds in very young children. On the basis of our results, we hypothesize that an underarousal pattern may play a role in the spectrum of effects measured in toddlers prenatally exposed to PCBs and dioxin-like compounds.

\section{Supplementary Information}

The online version contains supplementary material available at https://doi. org/10.1186/s12887-021-02533-2.

Additional file 1.

Additional file 2.

Additional file 3.

Additional file 4. 


\section{Abbreviations}

BMl: Body Mass Index; CALUX-TEQ: Dioxin-like activity measured via the CALUX ${ }^{\oplus}$ assay; DDE: P, $p^{\prime}$-dichlorodiphenyldichloroethylene; HCB: Hexachlorobenzene; HOME: Home Observation Measurement of the Environment; IBQ: Infant Behavior Questionnaire; IQ: Intelligence quotient; NES: Neurobehavioral Evaluation System; PCB: Polychlorinated biphenyls; POPs: Persistent organic pollutants; PS IQ : Performance Scale IQ (SON); RS IQ: Reasoning Scale IQ (SON); RTOS: Reynell TaalOntwikkelingsSchalen (language development); SD: Standard Deviation; SON: Snijders-Oomen Nietverbale intelligentietest (non-verbal intelligence); SON-IQ : Total intelligence scale (SON); STAI: State-Trait Anxiety Inventory; SumPCB: Sum of polychlorinated biphenyls; WASI: Wechsler Abbreviated Scale of Intelligence

\section{Acknowledgements}

This study was commissioned and financed by the Ministry of the Flemish Community (Department of Economics, Science and Innovation; Flemish Agency for Care and Health; and Department of Environment, Nature and Energy). A report containing the methods and the results for part of the subjects has been submitted to the Flemish Government that funded the research. This work has not been previously submitted elsewhere. We wish to thank for their competent collaboration Rita Verachtert, Mieke Thijs, Jan Laenen and Natalie Verelst from the Flemish Agency for Mental Health, Prof. B. Van Den Bergh, Ine Nijs, Lien Van Laer and Veerle Nullens from the Faculty of Psychology, KU Leuven, Prof. F. Comhaire of the department of Endocrinology of Ghent University, the field workers of the Provinciaal Institut voor Hygiëne (Antwerp) and Liesbeth Bruckers from the Interuniversity Institute for Biostatistics and statistical Bioinformatics, Universiteit Hasselt.

\section{Authors' contributions}

GV participated in data collection, in the statistical analysis and in the writing of the manuscript. AC was responsible for the measurement of organochlorines in cord blood. NVL participated in the organization of the project, in the statistical analysis and in the writing of the manuscript. GS participated in the organization of the project and was responsible for the measurement of dioxin-like activity in cord blood. VN participated in data collection and in the organization of the project. GK participated in biomonitoring analyses. MV participated in the organization of the project, in data collection, in the statistical analysis and in the writing of the manuscript. All authors have read and approved the manuscript.

\section{Funding}

This study was commissioned and financed by the Ministry of the Flemish Community (Department of Economics, Science and Innovation; Flemish Agency for Care and Health; and Department of Environment, Nature and Energy). The sponsor was not involved in analysis and interpretation of the data, nor in the decision to publish the data.

\section{Availability of data and materials}

The aggregated data are publically available via the IPCHEM data platform (https://ipchem.jrc.ec.europa.eu/RDSIdiscovery/ipchem/index.html\#discovery). The individual records can be requested via the procedures that are available on this portal (https://ipchem.jrc.ec.europa.eu/RDSIdiscovery/ipchem/index. html\#showmetadata/FLEHS1REFNB).

\section{Ethics approval and consent to participate}

The study protocol was approved by the Ethical Committee of the University of Antwerp on July 3, 2002.

\section{Consent for publication}

Not applicable.

\section{Competing interests}

The authors declare that they have no competing interests.

\section{Author details}

${ }^{1}$ Neurotoxicology Expertise Center, Public psychiatric care centre Geel, Pas 200, 2440 Geel, Belgium. ${ }^{2}$ Toxicological Centre, University of Antwerp, Campus Drie Eiken ,DS551, Universiteitsplein 1, 2610 Wilrijk, Belgium. ${ }^{3}$ Department of Radiotherapy and Experimental Cancerology, Ghent University, De Pintelaan 185, 9000 Gent, Belgium. ${ }^{4}$ Analytical, Environmental and Geochemistry, Vrije Universiteit Brussel, Pleinlaan 2, 1050 Brussels, Belgium. ${ }^{5}$ Vlaamse Instelling voor Technologisch Onderzoek (VITO), Environmental Toxicology Unit, Mol, Belgium. ${ }^{6}$ Provinciaal Institut voor Hygiëne, Kronenburgstraat 45, 3000 Antwerpen, Belgium. ${ }^{7}$ Departement of Environment and Health, faculty of medicine, KU Leuven, Kapucijnenvoer 35-D-box 7001, 3000 Leuven, Belgium. ${ }^{8}$ Department of Neurology, General Hospital Geel, J.B. Steffensstraat 2, 2440 Geel, Belgium.

Received: 11 May 2020 Accepted: 2 February 2021

Published online: 26 February 2021

\section{References}

1. Nawrot TS, Staessen JA, Den Hond EM, Koppen G, Schoeters G, Fagard R, Thijs L, Winneke G, Roel HA. Host and environmental determinants of polychlorinated aromatic hydrocarbons in serum of adolescents. Enviro Health Perspect. 2002;110:583-9.

2. Berghuis SA, Roze E. Prenatal exposure to PCBs and neurological and sexual/pubertal development from birth to adolescence. Curr Probl Pediatr Adolesc Health Care. 2019;49:133-59.

3. Van Birgelen AP. Hexachlorobenzene as a possible major contributor to the dioxin activity of human milk. Environ Health Perspect. 1998;106:683-8.

4. De Coster S, van Larebeke N. Endocrine-Disrupting Chemicals: Associated Disorders and Mechanisms of Action. J Environ Public Health. 2012, Article ID 713696, 2012:52. https://doi.org/10.1155/2012/713696.

5. Faroon $\mathrm{O}$, Jones $\mathrm{D}$, de Rosa $\mathrm{C}$. Effects of polychlorinated biphenyls on the nervous system. Toxicol Ind Health. 2000;16:305-33.

6. Boix J, Cauli O. Alteration of serotonin system by polychlorinated biphenyls exposure. Neurochem Int. 2012;60:809-16.

7. Kodavanti PR, Tilson HA. Neurochemical effects of environmental chemicals: in vitro and in vivo correlations on second messenger pathways. Ann N Y Acad Sci. 2000;919:97-105.

8. Maervoet J, Vermeir G, Covaci A, Van Larebeke N, Koppen G, Schoeters G, Nelen V, Baeyens W, Schepens P, Viaene MK. Association of thyroid hormone concentrations with levels of organochlorine compounds in cord blood of neonates. Environ Health Perspect. 2007;115:1780-6.

9. Klocke C, Sethi S, Lein PJ. The developmental neurotoxicity of legacy vs. contemporary polychlorinated biphenyls (PCBs): similarities and differences. Environ Sci Pollut Res. 2020;27:8885-96.

10. Vreugdenhil HJ, Slijper FM, Mulder PG, Weisglas-Kuperus N. Effects of perinatal exposure to PCBs and dioxins on play behaviour in Dutch children at school age. Environ Health Perspect. 2002;110:593-8.

11. Guo YL, Lai TJ, Chen SJ, Hsu CC. Gender-related decrease in Raven's progressive matrices scores in children prenatally exposed to polychlorinated biphenyls and related contaminants. Bull Environ Contam Toxicol. 1995;55:8-13.

12. Gore AC. Developmental programming and endocrine disruptor effects on reproductive neuroendocrine systems. Front Neuroendocrinol. 2008;29:358-74.

13. Gore AC. Neuroendocrine targets of endocrine disruptors. Hormones. 2010; 9:16-27.

14. Bradley RH. Children's home environments, health, behavior, and intervention efforts: a review using the HOME inventory as a marker measure. Genet Soc Gen Psychol Monogr. 1993;19:437-90.

15. Bradley RH, Caldwell BM. Home observation for measurement of the environment: a revision of the preschool scale. Am J Ment Defic. 1979;84: 235-44.

16. Wechsler D, Van der Steene G, Vertommen H, Bleichrodt N, Uiterwijk JM. WAIS-III Nederlandstalige bewerking. Amsterdam: Swets \& Zeitlinger; 2000

17. van der Ploeg HM. De Zelf-Beoordelings Vragenlijst (STAI-DY). De ontwikkeling en validatie van een Nederlandstalige vragenlijst voor het meten van angst. Tijdschrift Voor Psychiatrie. 1982;24:576-88.

18. Gómara B, Ramos L, González MJ. Determination of polychlorinated biphenyls in small-size serum samples by solid-phase extraction followed by gas chromatography with micro-electron-capture detection. J Chromatogr B Analyt Technol Biomed Life Sci. 2002;766:279-87.

19. Covaci A, Voorspoels S, Thomsen C, van Bavel B, Neels H. Evaluation of total lipids using enzymatic methods for the normalization of persistent organic pollutant levels in serum. Sci Total Environ. 2006;366:361-6.

20. Koppen G, Covaci A, Van Cleuvenbergen R, Schepens P, Winneke G, Nelen $V$, Schoeters G. Comparison of CALUX-TEQ values with PCB and PCDD/F measurements in human serum of the Flanders environmental and health study (FLEHS). Toxicol Lett. 2001;123:59-67. 
21. Van der Meulen BF, Ruiter SAJ, Lutje Spelberg HC, Smrkovský M. Bayley scales of infant development (BSID) - II. Nederlandse versie. Amsterdam: Swets \& Zeitlinger; 2002.

22. Rothbart MK. Measurement of temperament in infancy. Child Dev. 1981;52: 569-78.

23. Schaerlaekens A, Zink I, Van Ommeslaeghe K. Reynell Taalontwikkelingsschalen (RTOS). Amsterdam: Pearson; 2003.

24. Tellegen PJ, Winkel M, Wijnberg-Williams BJ, Laros JA. Snijders-Oomen nietverbale intelligentietest SON-R 21/2-7, handleiding en verantwoording [Snijders-Oomen Non-verbal Intelligence Test SON-R 2 1/2-7. Manual]. Lisse (Netherlands): Swets \& Zeitlinger; 1998.

25. Berenbaum SA, Hines M. Early androgynes are related to childhood sextyped toy preferences. Psychol Sci. 1992;3:203-6.

26. Servin A, Bohlin G, Berling L. Sex differences in 1-, 3- and 5-year-olds' toy choice in a structured play session. Scand J Psychol. 1999;40:43-8.

27. Letz R, Dilorio CK, Shafer PO, Yeager KA, Schomer DL, Henri TR. Futher standardisation of some NES3 tests. Neurotoxicoly. 2003;24:491-501.

28. Patandin S, Veenstra J, Mulder PGH, Sewnaik A, Sauer PJJ, Weisglas-Kuperus N. Attention and activity in 42-month-old Dutch children with environmental exposure to polychlorinated biphenyls and dioxins. In: Effects of Environmental Exposure to Polychlorinated Biphenyls and Dioxins on Growth and Development in Young Children. Patandin, S. Thesis. Rotterdam: Erasmus University; 1999b. p. 123-42.

29. Shang L, Yang L, Yang W, Huang L, Qi C, Yang Z, Fu Z, Chung MC. Effects of prenatal exposure to NO2 on children's neurodevelopment: a systematic review and meta-analysis. Environ Sci Pollut Res Int. 2020;27(20):24786-98.

30. Zhang H, Yolton K, Webster GM, Sjödin A, Calafat AM, Dietrich KN, Xu Y, Xie C, Braun JM, Lanphear BP, Chen A. Prenatal PBDE and PCB exposures and reading, cognition, and externalizing behavior in children. Environ Health Perspect. 2017;125:746-52.

31. Berghuis SA, Van Braeckel KNJA, Sauer PJJ, Bos AF. Prenatal exposure to persistent organic pollutants and cognition and motor performance in adolescence. Environ Int. 2018;121:13-22.

32. Kim S, Eom S, Kim HJ, Lee JJ, Choi G, Choi S, Kim S, Kim SY, Cho G, Kim YD, Suh E, Kim SK, Kim S, Kim GH, Moon HB, Park J, Kim S, Choi K, Eun SH. Association between maternal exposure to major phthalates, heavy metals, and persistent organic pollutants, and the neurodevelopmental performances of their children at 1 to 2 years of age- CHECK cohort study. Sci Total Environ. 2018;624:377-84.

33. Rosenquist $A H$, Hoyer BB, Julvez J, Sunyer J, Pedersen HS, Lenters $V$, Jonsson BA, Bonde JP, Toft G. Prenatal and Postnatal PCB-153 and p,p'-DDE Exposures and Behavior Scores at 5-9 Years of Age among Children in Greenland and Ukraine. Environ Health Perspect. 2017;125(10):CID 107002. https://doi.org/10.1289/EHP553.

34. Kyriklaki A, Vafeiadi M, Kampouri M, Koutra K, Roumeliotaki T, Chalkiadaki G, Anousaki D, Rantakokko P, Kiviranta H, Fthenou E, Bitsios P, Kyrtopoulos SA, Kogevinas M, Chatzi L. Prenatal exposure to persistent organic pollutants in association with offspring neuropsychological development at 4 years of age: the Rhea motherchild cohort, Crete. Greece Environ Int. 2016;97:204-11.

35. Rogan WJ, Glaben BC, McKinney JD, Carreras N, Hardy P, Thullen J, Tinglestad J, Tully M. Neonatal effects of transplacental exposure of PCBs and DDE. J Pediatr. 1986;109:335-41.

36. Jacobson $J \mathrm{~L}$, Jacobson SW. Intellectual impairment in children exposed to polychlorinated biphenyls in utero. N Engl J Med. 1996;335:783-9.

37. Winneke G, Bucholski A, Heinzbow B, Kramer U, Schmidt E, Walkowiak J, Wiener JA, Steingrüber HJ. Developmental neurotoxicity of polychlorinated biphenyls (PCBs): cognitive and psychomotor functions in 7-month old children. Toxicol Let. 1998:102-103:423-8.

38. Patandin S, Lanting Cl, Mulder PG, Boersma ER, Sauer PJ, Wiesglas-Kuperus $\mathrm{N}$. Effects of environmental exposure to polychlorinated biphenyls and dioxins on cognitive abilities in Dutch children at 42 months of age. J Pediatr. 1999a;134(1):33-41.

39. Huisman M, Koopman-Esseboom C, Fidler V, Hadders-Algra M, van der Paauw CG, Tuinstra LG, Weisglas-Kuperus N, Sauer PJ, Touwen BC, Boersma ER. Perinatal exposure to polychlorinated biphenyls and dioxins and its effect on neonatal neurological development. Early Hum Dev. 1995a;41:111-27.

40. Huisman M, Koopman-Esseboom C, Cl L, van der Paauw CG, Tuinstra LG, Fidler V, Weisglas-Kuperus N, Sauer PJ, Boersma ER, Touwen BC. Neurological conditions in 18-month-old children perinatally exposed to polychloirinated biphenyls and dioxins. Early Hum Dev. 1995b;41:165-76.
41. Steuerwald UP, Weihe PJ, Jorgensen K, Bjerve K, Brock J, Heinzow B, BudtzJorgensen E, Grandjean P. Maternal seafood diet, methylmercury exposure, and neonatal neurologic function. J Pediatr. 2000;136(5):599-605.

42. Guo YL, Lambert GH, Hsu C-C, Hsu MM. Yucheng: health effects of prenatal exposure to polychlorinated biphenyls and dibenzofurans. Int Arch Occup Environ Health. 2004;177:153-8.

43. Boucher O, Muckle G, Ayotte P, Dewailly E, Jacobson SW, Jacobson JL. Altered fine motor function at school age in Inuit children exposed to PCBs, methylmercury, and lead. Environ Int. 2016;95:144-51.

44. Sajaniemi N, Salokorpi T, von Wendt L. Temperament profiles and their role in neurodevelopment assessed preterm children at two years of age. Eur Child Adolesc Psychiatry. 1998;7(3):145-52.

45. Gartstein MA, Rothbart MK. Studying infant temperament with revised infant behavior questionnaire. Infant Behav Dev. 2003;26:64-86.

46. Gartstein MA, Skinner MK. Prenatal influences on temperament development: the role of environmental epigenetics. Dev Psychopathol. 2018;30:1269-303.

47. Rush D, Callahan KR. Exposure to passive cigarette smoking and child development. A critical review. Ann N Y Acad Sci. 1989;562:74-100.

48. Jacobson $\mathrm{J}$, Jacobson SW, HEB H. Effects of exposure to PCBs and related compounds on growth and activity in children. Neurotoxicol Teratol. 1990; 12:319-26.

49. Kaufman AS. Critique of Vreugdenhil et al.'s study linking PCBs to the play behaviors of Dutch girls and boys. Environ Health Perspect. 2003;111(7): A380-1.

50. Breckenridge K, Braddick O, Atkinson J. The organization of attention in typical development: a new preschool attention test battery. $\mathrm{Br} J \mathrm{~J}$ ev Psychol. 2013;31:271-88.

51. Jacobson JL, Jacobson SW, Padgett RJ, Brummitt GA, Billings L. Effects of prenatal PCB exposure on cognitive processing efficiency and sustained attention. Dev Psychol. 1992;28(2):297-306.

52. Stewart P, Fitzgerald S, Reihman J, Gump B, Lonky E, Darvill T, Pagano J, Hauser P. Prenatal PCB exposure, the corpus callosum, and response inhibition. Environ Health Perspect. 2003:111(13):1670-7.

53. Jacobson JL, Jacobson SW. Breastfeeding and gender as moderators of teratogenic effects on cognitive development. Neurotoxicol Teratol. 2002;24: 349-58.

54. Jacobson JL, Jacobson SW. Prenatal exposure to polychlorinated biphenyls and attention at school age. J Paediatr. 2003;143(6):780-8.

55. Vreugdenhil HJ, Mulder PG, Emmen HH, Weisglas-Kuperus N. Effects of perinatal exposure to PCBs on neuropsychological function in the Rotterdam cohort at 9 years of age. Neuropsychology. 2004;18(1):185-93.

56. Caspersen $1 \mathrm{H}$, Haugen M, Schjolberg S, Vejrup K, Knutsen HK, Brantsaeter AL, Meltzer HM, Alexander J, Magnus P, Kvalem HE. Maternal dietary exposure to dioxins and polychlorinated biphenyls (PCBs) is associated with language delay in 3year old Norwegian children. Environ Int. 2016a;91:180-7

57. Caspersen $\mathrm{H}_{\text {, Aase }} \mathrm{H}$, Biele $\mathrm{G}$, Brantsaeter AL, Haugen M, Kvalem HE, Skogan AH, Zeiner P, Alexander J, Meltzer HM, Knutsen HK. The influence of maternal dietary exposure to dioxins and PCBs during pregnancy on ADHD symptoms and cognitive functions in Norwegian preschool children. Environ Int. 2016b;94:649-60.

58. Ikeno T, Miyashita C, Nakajima S, Kobayashi S, Yamazaki K, Saijo Y, Kita T, Sasaki S, Konishi K, Kajiwara J, Hori T, Kishi R. Effects of low-level prenatal exposure to dioxins on cognitive development in Japanese children at 42months. Sci Total Environ. 2018;618:1423-30.

59. Karkaba A, Soualeh N, Soulimani R, Bouayed J. Perinatal effects of exposure to PCBs on social preferences in young adult and middle-aged offspring mice. Horm Behav. 2017:96:137-46.

60. Miller MM, Meyer AE, Sprowles JL, Sable HJ. Cocaine self-administration in male and female rats perinatally exposed to PCBs: evaluating drug use in an animal model of environmental contaminant exposure. Exp Clin Psychopharmacol. 2017;25(2):114-24.

61. Bell MR, Thompson LM, Rodriguez K, Gore AC. Two-hit exposure to polychlorinated biphenyls at gestational and juvenile life stages: 1. Sexually dimorphic effects on social and anxiety-like behaviors. Horm.Behav. 2016;78: 168-77.

62. Cauli O, Piedrafita B, Llansola M, Felipo V. Gender differential effects of developmental exposure to methyl-mercury, polychlorinated biphenyls 126 or 153 , or its combinations on motor activity and coordination. Toxicology. 2013;311:61-8. 
63. Schantz SL, Widholm J. Cognitive effects of endocrine disrupting chemicals in animals. Environ Health Perspect. 2001;109:1197-206.

64. Cao Y, Winneke G, Wilhelm M, Wittsiepe J, Lemm F, Fürst P, Ranft U, Imöhl L, Kraft M, Oesch-Bartlomowicz B, Kramer U. Environmental exposure to dioxins and polychlorinated biphenyls reduce levels of gonadal hormones in newborns: results from the Duisburg cohort study. Int J Hyg Environ Health. 2008;211:30-9.

65. Colciago A, Casati L, Mornati O, Vergoni AV, Santagostino A, Celotti F, NegriCesi P. Chronic treatment with polychlorinated biphenyls (PCB) during pregnancy and lactation in the rat part 2: effects on reproductive parameters, on sex behavior, on memory retention and on hypothalamic expression of aromatase and 5alpha-reductases in the offspring. Toxicol Appl Pharmacol. 2009;239:46-54.

66. Topper W, Reilly MP, Wagner LM, Thompson LM, Gillette R, Crews D, Gore AC. Social and neuromolecular phenotypes are programmed by prenatal exposures to endocrine-disrupting chemicals. Mol Cell Endocrinol. 2019;479:133-46.

67. De Coster S, van Leeuwen DM, Jennen DG, Koppen G, Den Hond E, Nelen V, Schoeters G, Baeyens W, van Delft JH, Kleinjans JC, Van Larebeke N. Gender-specific transcriptomic response to environmental exposure in Flemish adults. Environ Mol Mutagen. 2013;54(7):574-88.

\section{Publisher's Note}

Springer Nature remains neutral with regard to jurisdictional claims in published maps and institutional affiliations.

Ready to submit your research? Choose BMC and benefit from:

- fast, convenient online submission

- thorough peer review by experienced researchers in your field

- rapid publication on acceptance

- support for research data, including large and complex data types

- gold Open Access which fosters wider collaboration and increased citations

- maximum visibility for your research: over $100 \mathrm{M}$ website views per year

At $\mathrm{BMC}$, research is always in progress.

Learn more biomedcentral.com/submissions 